\title{
PENGEMBANGAN SENTRA WISATA BERBASIS POTENSI LOKAL MELALUI PROGRAM PENGEMBANGAN DESA MITRA
}

\author{
Iin Purnamasari ${ }^{1}$ \\ Ikhwanudin $^{2}$ \\ Ndaru Hario Sutaji ${ }^{3}$ \\ Ekasari Setianingsih $^{4}$ \\ Universitas PGRI Semarang \\ rengganis_husaini@yahoo.com,
}

\begin{abstract}
ABSTRAK
Program Pengembangan Desa Mitra (PPDM) secara khusus bertujuan untuk menghilirisasikan hasil riset unggulan Universitas PGRI Semarang antara lain penelitian kaji tindak di Fakultas Teknik seperti penataan kawasan permukiman untuk melakukan penataan desa Sepakung sebagai kawasan wisata berbasis potensi alam. Hasil penelitian lain adalah bidang pendidikan yang diterapkan untuk pendidikan wisata, serta pemberdayaan masyarakat menuju desa wisata mandiri. Metode PPDM dilakukan dengan tahap persiapan, tahap pemberdayaan masyarakat yang meliputi pembinaan, pendampingan, dan evaluasi dalam semua kegiatan serta tahap menuju desa wisata. Kegiatan dilaksanakan dalam waktu tiga (3) tahun, dengan fokus utama pada tahun ke-1 adalah pengembangan sentra usaha kecil berbahan ketela mangul bagi kelompok UKM, pembentukan Kelompok Guidance Tourism (GT) bagi kelompok Karang Taruna, dan pembuatan Site/Master Plan Kawasan wisata cagar alam Desa Sepakung bagi Kelompok Sadar Wisata (POKDARWIS).
\end{abstract}

Kata Kunci: sentra wisata, potensi lokal, desa mitra

\section{LATAR BELAKANG}

Desa Sepakung secara administratif merupakan wilayah di kecamatan Banyubiru kabupaten Semarang dengan potensi unggulan yang tidak terlepas dari letak geografis dan kekayaan alam sebagai modal yang harus dikelola secara optimal. Nilai keindahan alam yang dimiliki tersebut telah direspon oleh Pemerintah Kabupaten Semarang melalui SK Bupati Semarang No. 556/0424/2015 tentang Penetapan Desa Wisata di Kabupaten Semarang, bersama dengan desa Kebondowo dan Potensi-potensi di atas mendukung program pengembangan di sektor tanaman pangan, perkebunan dan peternakan guna menciptakan terpenuhinya kebutuhan bagi masyarakat dan mendorong perekonomian desa. Berbagai komoditi potensial desa Sepakung diantaranya adalah tanaman pangan, buah-buahan, tanaman hias, sayuran, dengan sentra yang tersebar hampir di setiap dusun (Profil Desa Sepakung, LPDP Tahun Anggaran 2015). Mayoritas mata pencaharian penduduk adalah petani dan buruh tani.

Potensi-potensi di atas mendukung program pengembangan di sektor tanaman pangan, perkebunan dan peternakan guna menciptakan terpenuhinya kebutuhan bagi masyarakat dan mendorong perekonomian desa. Berbagai komoditi potensial desa Sepakung diantaranya adalah tanaman pangan, buah-buahan, tanaman hias, sayuran, dengan sentra yang tersebar hampir di setiap dusun (Profil Desa Sepakung, LPDP Tahun Anggaran 2015). Mayoritas mata pencaharian penduduk adalah petani dan buruh tani.

Pada Program Pengembangan Desa Mitra (PPDM) tahun ke-1 ini, telah dilakukan pengembangan dan pengolahan tanaman pangan dan hasil pertanian lain di desa Sepakung, salah

\footnotetext{
${ }^{1}$ Dosen Program Studi PGSD Fakultas Ilmu Pendidikan Universitas PGRI Semarang

2 Dosen Program Studi Teknik Sipil Fakultas Teknik Universitas PGRI Semarang

${ }^{3}$ Dosen Program Studi Teknik Arsitektur Fakultas Teknik Universitas PGRI Semarang

${ }^{4}$ Dosen Program Studi PGSD Fakultas Ilmu Pendidikan Universitas PGRI Semarang
} 
satunya adalah Ubi Mangul atau masyarakat setempat menyebut dengan telo mangul, dalam aneka olahan yaitu kue-kue kering. Hal tersebut dilakukan dalam rangka mengubah daya guna dan mengembangkan ekonomi kreatif masyarakat dengan memanfaatkan perbedaan karakter ketela dibandingkan dengan jenis yang lain, baik dari segi rasa, maupun kekenyalannya. Dalam hal ini, ubi mangul yang juga dianggap memiliki nilai historis tersendiri bagi masyarakat desa Sepakung, sangat layak untuk dikembangkan dalam aneka olahan makanan ringan yang dikemas sebagai salah satu pendukung menuju desa wisata, yang akan melengkapi kekhasan produksi makanan kecil desa Sepakung dan mendukung program desa wisata.

Sesuai dengan tujuan khusus dari Program Pengembangan Desa Mitra (PPDM) ini dispesifikasikan dalam tiga tahap pada tahun pertama, kedua dan ketiga. Adapun program pada tahun ke-1 adalah Pengembangan sentra usaha kecil berbahan ketela mangul bagi kelompok UKM, pembentukan Kelompok Guidance Tourism (GT) bagi kelompok Karang Taruna, dan pembuatan Site Plan/Master Plan Potensi Wisata Desa Sepakung bagi Kelompok Sadar Wisata (POKDARWIS).

Ketela mangul memiliki keistimewaan karena hanya ada semusim dalam setahun dan hanya tumbuh di Desa Sepakung. Panen setahun sekali, biasanya di awal musim hujan. Pernah dicoba ditanam di luar desa, kualitasnya berbeda. Salah satu keistimewaan ketela mangul dibandingkan ketela lain adalah dari segi rasa dan ukuran. Ketela mangul rasanya manis, dagingnya kisat (kering) dan putih masir (berbutir-butir) jika dikukus. Bobot satu buah ketela mangul bisa mencapai hingga empat kilogram. Lantaran hanya ada semusim dalam satu tahun dan tidak dijual di pasar, ketela mangul selalu diburu oleh para penikmatnya. Harganya pun lebih mahal dari ketela biasa, yakni Rp 3.000 per kilogram. Di Desa Sepakung, ketela mangul ditanam di sawah tadah hujan. Di lahan seluas 20 hektar bisa mendatangkan hasil panen mencapai lebih dari 100 ton. Ketela mangul biasanya dijual langsung kepada konsumen atau dipesan langsung dengan harga yang murah. Oleh karena itu, ketela mangul ini diinovasikan dalam beberapa pengembangan aneka olahan dengan pendampingan terhadap kelompok UKM yang telah ditetapkan sebagai mitra kegiatan.

Target capaian program tahun ke-1 yang lain dalam PPDM ini, juga telah dibentuk kelompok Guidance Tourisme atau pemandu wisata lokal yang diharapkan dapat mengelola pengembangan sentra wisata desa. Adapun kegiatan lain berupa pendampingan penyusunan dan penggunaan master plan desa wisata Sepakung, serta pengajuan Pangan Industri Rumah Tangga/PIRT untuk olahan ketela mangul.

\section{METODE PELAKSANAAN}

Program pengembangan sentra wisata Sepakung dilaksanakan secara bertahap. Adapun kegiatan pada setiap tahap dilaksanakan menggunakan metode yang disepakati oleh tim pengabdi bersama dengan mitra. Berikut adalah desain tahapan kegiatan yang dilaksanakan dengan metode. 


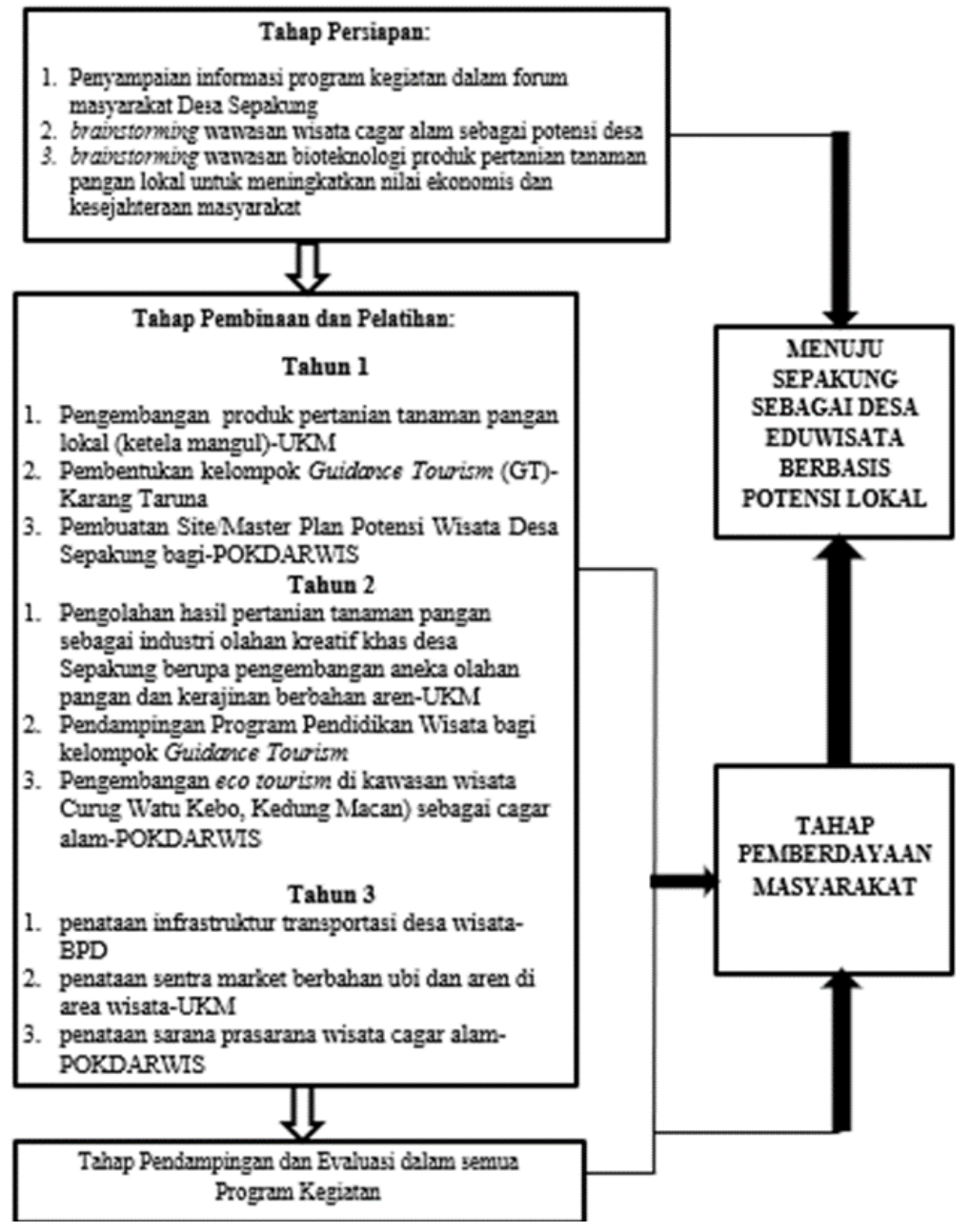

Gambar 2. Konsep dan Metode Pelaksanaan Program

Pelaksanaan program sebagaimana disajikan dalam bagan di atas menunjukkan saat ini program yang telah dilaksanakan pada tahun ke-1. Tahapan yang dilakukan berupa tahap persiapan yang meliputi penyampaian informasi program kegiatan dalam forum masyarakat desa Sepakung, brainstorming wawsan wisata cagar alam sebagai potensi desa, brainstorming wawasan bioteknologi produk pertanian tanaman pangan lokal untuk meningkatkan nilai ekonomis dan kesejahteraan masyarakat. Tahapan selanjutnya adalah tahap pembiasaan dan pelatihan, terutama untuk program kegiatan di tahun 1. Tahapan terakhir adalah pendamppingan dan evaluasi dimana telah dilakukan pendampingan terhadap kelompok UKM KWT Srikandi dalam pengembangan aneka olahan berbahan ketela mangul, pokdarwis dalam penyusunan masterplan dan karang taruna dalam pembentukan Guidance Tourisme.

\section{HASIL DAN PEMBAHASAN}

\section{a. Pendampingan Pengembangan Sentra Usaha Kecil Berbahan Ketela Mangul.}

Pada program ini telah dilakukan pendampingan dalam 2 tahap terhadap kelompok Usaha Kecil Menengah/UKM yaitu UKM Srikandi. Kegiatan tersebut dapat diuraikan sebagai berikut.

Tahap pertama, kegiatan Sosialisasi Teknologi Tepat Guna: Proses Pembuatan Tepung Ketela Mangul. Dalam hal ini tim PPDM menghadirkan narasumber sekaligus Dosen dan Kepala Laboratorium Teknologi Pangan, Fakultas Teknik Universitas PGRI Semarang yaitu Mohammad Arif Rakhman, ST., MT. Jumlah anggota UKM yang hadir sebanyak 25, bertempat di Balai Desa 
Sepakung Kecamatan Banyubiru Kabupaten Semarang, pada hari Sabtu, 26 Mei 2018. Dalam hal ini narasumber memberikan penjelasan dan praktik penepungan pada ketela mangul serta berbagai pengembangan yang memungkinkan dapat dilakukan oleh kelompok UKM.

Tahap Kedua, kegiatan pengembangan aneka olahan ketela mangul melalui pelatihan yang diselenggarakan di Laboratorium Teknologi Pangan Universitas PGRI Semarang, pada tanggal 16 Juni 2018. Dalam hal ini pendampingan dilakukan oleh Tim PPDM yang melibatkan trainer di bidang teknologi pangan, sebagai kelanjutan dari kegiatan di tahap 1. Dalam pelatihan ini juga melibatkan 5 mahasiswa teknologi pangan yang secara langsung mendampingi kelompok UKM sebagai mitra PPDM. Selanjutnya, telah diproduk aneka kue kering berbahan ketela mangu. Dari pengembangan hasil olahan ini selanjutnya dikembangkan oleh UKM sebagai produk unggulan yang mendukung program desa wisata Sepakung. Berikut adalah sajian penilaian peserta sosialisasi dan pelatihan.

Tabel 1. Penilaian Peserta terhadap Program Pengembangan Aneka Olahan Berbahan Ketela Mangul

\begin{tabular}{|l|l|c|}
\hline NO & \multicolumn{1}{|c|}{ ASPEK } & $\begin{array}{c}\text { HASIL PENILAIAN } \\
\text { RATA-RATA } \\
\text { (\%) }\end{array}$ \\
\hline $\mathbf{1}$ & $\begin{array}{l}\text { Sosialisasi teknologi tepat guna dalam pengolahan ketela } \\
\text { mangul menjadi alternatif pemberdayaan masyarakat } \\
\text { untuk meningkatkan penghasilan warga }\end{array}$ & 90 \\
\hline $\mathbf{2}$ & $\begin{array}{l}\text { Pengembangan olahan ketela mangul dapat mendukung } \\
\text { program sentra wisata desa }\end{array}$ & 95 \\
\hline $\mathbf{3}$ & $\begin{array}{l}\text { Hilirisasi peralatan pengolahan ketela mangul sangat } \\
\text { membantu kelompok usaha kecil menengah di desa }\end{array}$ & 100 \\
\hline $\mathbf{4}$ & $\begin{array}{l}\text { Pengolahan ketela mangul berorientasi meningkatkan } \\
\text { harga jual }\end{array}$ & 95 \\
\hline $\mathbf{5}$ & $\begin{array}{l}\text { Mendorong usaha kreatif dan inovatif dari UKM untuk } \\
\text { mengembangkan aneka produk berbahan ketela mangul } \\
\text { sebagai potensi lokal }\end{array}$ & 98 \\
\hline
\end{tabular}

Sumber: Data diolah, 2018

Berdasarkan tabel 1 dapat diketahui bahwa peserta sosialisasi dan pelatihan program pengembangan aneka olahan ketela mangul dari beberapa aspek yaitu sosialisasi teknologi tepat guna dalam pengolahan ketela mangul menjadi alternatif pemberdayaan masyarakat untuk meningkatkan penghasilan warga sebesar $90 \%$, pengembangan olahan ketela mangul dapat mendukung program sentra wisata desa 95\%, hilirisasi peralatan pengolahan ketela mangul sangat membantu kelompok usaha kecil menengah di desa sebesar $100 \%$, pengolahan ketela mangul berorientasi meningkatkan harga jual sebesar 95\%, dan mendorong usaha kreatif dan inovatif dari UKM untuk mengembangkan aneka produk berbahan ketela mangul sebagai potensi lokal sebesar 98\%. Dengan demikian dapat diketahui bahwa peserta sosialisasi dan pelatihan yang terdiri dari anggota UKM yaitu Kelompok Wanita Tani/KWT Srikandi dalam kategori penilaian yang sangat bagus.

\section{b. Pembentukan Kelompok Guidance Tourism (GT)}

Pelaksanaan program ini melibatkan kemitraan dengan kelompok Karang Taruna Ikatan Pemuda Desa Sepakung (IPDS); yang berkontribusi dalam pembentukan kelompok Pemandu Wisata/Guidance Tourisme (GT) lokal desa wisata Sepakung. Kelompok GT dibentuk oleh Kepala Desa Sepakung yang dikukuhkan dengan Surat Keputusan/SK Kepala Desa. Keanggotaan GT yang telah terbentuk pada tahun pertama ini, akan ditindaklanjuti untuk didampingi pada tahun kedua pada program Pendidikan Wisata dalam bentuk Short Course yang bersertifikat dari Lembaga Sertifikasi Profesi/LSP, sehingga di desa Sepakung terdapat kelompok yang khusus mengelola pelayanan kunjungan wisata di beberapa obyek.

GT dibentuk dengan dikukuhkan oleh Surat Keputusan/SK Kepala Desa Sepakung Nomor 141/016 Tahun 2018, yang terdiri dari 10 anggota dengan kedudukan sebagai penanggungjawab, ketua, sekretaris, dan anggota. Adapun tugas GT sebagaimana dicantumkan dalam SK tersebut 
adalah: (1) mengatur wisatawan baik rombongan maupun perorangan yang mengadakan perjalanan dan transportasi yang tersedia. (2) memberikan penjelasan dan mendampingi tentang rencana perjalanan dan obyek wisata, serta memberikan penjelasan mengenai dokumen perjalanan, akomodasi, transportasi, dan fasilitas wisatawan lainnya. (3) memberikan petunjuk tentang obyek wisata. (4) membantu menguruskan barang bawaan wisatawan, (5) memberikan pertolongan kepada wisatawan yang sakit, mendapat kecelakaan, kehilangan atau musibah lainnya. Berdasarkan penilaian yang telah diberikan oleh anggota POKDARWIS terhadap pembentukan GT diperoleh temuan sebagai berikut.

Tabel 2. Penilaian terhadap Program Pembentukan Guidance Tourisme pada Pengembangan Desa Mitra

\begin{tabular}{|l|l|c|}
\hline NO & \multicolumn{1}{|c|}{ ASPEK } & $\begin{array}{c}\text { HASIL PENILAIAN } \\
\text { RATA-RATA } \\
\text { (\%) }\end{array}$ \\
\hline $\mathbf{1}$ & $\begin{array}{l}|c| \\
\text { Pembentukan GT sesuai dengan kebutuhan mitra }\end{array}$ \\
\hline $\mathbf{2}$ & $\begin{array}{l}\text { Perencanaan Program GT dapat diterima oleh anggota } \\
\text { kelompok }\end{array}$ & 95 \\
\hline $\mathbf{3}$ & $\begin{array}{l}\text { Pendidikan kelompok GT sangat penting bagi } \\
\text { pengembangan sentra wisata }\end{array}$ \\
\hline $\mathbf{4}$ & $\begin{array}{l}\text { Keterlibatan tim dalam kegiatan program } \\
\text { pengembangan GT di desa mitra }\end{array}$ & 100 \\
\hline
\end{tabular}

Sumber: Data diolah, 2018

Berdasarkan tabel 2, diketahui bahwa anggota GT memberikan penilaian yang sangat bagus terhadap pelaksanaan program pembentukan kelompok Guidance Tourisme yang ditunjukkan pada aspek-aspek antara lain: (1) pembentukan GT sesuai dengan kebutuhan mitra sebesar $95 \%$, (2) perencanaan Program GT dapat diterima oleh anggota kelompok sebesar 98\%, (3) pendidikan kelompok GT sangat penting bagi pengembangan sentra wisata sebesar $100 \%$, (4) keterlibatan tim dalam kegiatan program pengembangan GT di desa mitra sebesar $100 \%$. Dengan demikian program pembentukan GT ini dapat dikatakan sesuai dengan kebutuhan mitra, dapat diterima oleh anggota kelompok,penting bagi pengembangan sentra wisata, dan tim terlibat sepenuhnya dalam kegiatan.

\section{c. Pembuatan Master Plan Potensi Wisata Desa Sepakung}

Program ini dilaksanakan dengan menyusun master plan eduwisata yang berisikan pemetaan permasalan, potensi dan perencanaan jangka menengah dan jangka panjang bagi desa Sepakung. Dalam program ini dilakukan beberapa tahap yang dimulai dari pelaksanaan Focus Group Discussion/FGD dan pendokumentasian data terkait potensi wisata desa Sepakung. FGD menghadirkan tim PPDM, praktisi Teknik Arsitektur Fakultas Teknik Universitas PGRI Semarang, jajaran aparat pemerintahan desa Sepakung, tim POKDARWIS, tokoh masyarakat dan unsur tokoh adat desa. Dalam hal ini dilakukan eksplorasi terhadap nilai-nilai historis-sosio-kultural pada setiap obyek wisata yang potensial di desa Sepakung. Pada tahap selanjutnya, dilakukan analisis data hasil FGD, pemetaan obyek wisata, pendokumentasian obyek-obyek wisata, pengukuran lokasi wisata, analisis pemetaan, pendirian papan informasi obyek wisata pada 7 lokasi yaitu obyek wisata gumuk reco, goa semar, bumi perkemahan dan petik sayur, curug kedung macan, sendang ari wulan, dan cemoro sewu. Hal lain yang dilakukan adalah penyusunan master plan eduwisata Sepakung.

Berdasarkan hasil dan pembahasan yang telah diuraikan, diperoleh pemahaman bahwa pelaksanaan program pengembangan sentra wisata melalui program pengembangan desa mitra yang telah dilakukan dinilai berada pada kategori sangat bagus, sebagaimana dalam indikator skor penilaian berikut. 
Tabel 3. Indikator Skor Penilaian

\begin{tabular}{|c|c|}
\hline SKOR RATA-RATA & NILAI \\
\hline $\mathbf{8 5 - 1 0 0}$ & Sangat Baik \\
\hline $\mathbf{7 0 - 8 4}$ & Baik \\
\hline $\mathbf{5 5 - 7 0}$ & Sedang \\
\hline $\mathbf{4 0 - 5 4}$ & Kurang \\
\hline$\leq \mathbf{4 0}$ & Jelek \\
\hline
\end{tabular}

\section{KESIMPULAN}

Berdasarkan hasil dan pembahasan diketahui bahwa program pengembangan desa mitra dapat mendukung dan mewujudkan pengembangan sentra wisata desa Sepakung. Beberapa hasil kegiatan adalah pengembangan aneka olahan berbahan ketela mangul sebagai potensi lokal desa Sepakung, pembentukan kelompok Guidance Tourisme yang melibatkan kelompok Karang Taruna dan penyusunan masterplan eduwisata desa Sepakung yang melibatkan mitra dari kelompok sadar wisata/POKDARWIS.

\section{DAFTAR PUSTAKA}

LPDP. 2016. Profil Desa Sepakung Kecamatan Banyubiru Kabupaten Semarang Tahun 2016 Rencana Pembangunan Jangka Menengah Desa Sepakung 2014-2019

SK Bupati Semarang No. 556/0424/2015 tentang Penetapan Desa Wisata di Kabupaten Semarang

Susanto. D.A. dkk. 2014. Pemberdayaan Masyarakat Kelurahan Kandri Kecamatan Gunung Pati Kota Semarang Berbasis Kearifan Lokal Menuju Desa Wisata Mandiri. Hasil Riset UPGRISCSR (Bank Jateng)-Pemerintah Kota Semarang dalam Program GERDU Kempling tahun 2014

Sulistyoningsih. M. dkk. 2015. Revitalisasi Sentra Industri Pangan Lokal Melalui Pemberdayaan Warga Pra-sejahtera Kelurahan Batursari Kecamatan Mranggen. Hasil Riset UPGRIS-CSR (Bank Mandiri)- Pemerintah Kota Semarang dalam Prograam GERDU Kempling tahun 2015

Surat Keputusan Bupati Semarang Nomor 556/0424/2015 Tentang Penetapan Desa Wisata Di Kabupaten Semarang

UU No.6 Tahun 2014 tentang Desa

\section{UCAPAN TERIMA KASIH}

Terima kasih disampaikan kepada DRPM Kemenristek Dikti yang telah memberikan kesempatan untuk melaksanakan usulan program, Rektor Universitas PGRI Semarang atas ijin yang diberikan terkait pelaksanaan Pengabdian kepada Masyarakat skema PPDM, LPPM Universitas PGRI Semarang, Tim PPDM Universitas PGRI Semarang yang solid dalam menjalankan semua program. 